\title{
Responsiveness of Neoplastic and Hyperplastic Parathyroid Tissues to Calcium In Vitro
}

\author{
JoEl F. HABENER, Endocrine Unit, Massachusetts General Hospital, and Department \\ of Medicine, Harvard Medical School, Boston, Massachusetts 02114
}

A B S T R A C T Secretory and biosynthetic responses of adenomatous, carcinomatous, and hyperplastic parathyroid tissues to variable concentrations of extracellular calcium were assessed in vitro. Tissues, obtained at the time of parathyroidectomy, were incubated for $4 \mathrm{~h}$ in media containing radioactive amino acids and varying (0.5-5.0 $\mathrm{mM})$ concentrations of calcium. Amounts of newly synthesized and total parathyroid hormone and proparathyroid hormone in extracts of tissues and media were measured by polyacrylamide gel electrophoresis and by radioimmunoassay, respectively. All tissues studied (six adenomas, two specimens of chief-cell hyperplasia, one carcinoma, and normal bovine and human glands) responded to changes in calcium concentrations; decreasing concentrations of calcium stimulated release and decreased tissue storage of hormone. Six of the abnormal tissues required greater than normal concentrations of calcium (1.8$2.4 \mathrm{mM}$ for $50 \%$ of effect) to elicit secretory responses comparable with those of normal glands (1.4 mM). Maximum effects of calcium on release of hormone varied from 2- to 10-fold among different tissues. Release of some hormone persisted even in concentrations of calcium as high as $5.0 \mathrm{mM}$. Relative amounts of hormone released from and retained in the tissues varied greatly among the tissues, as did the absolute amounts of hormone produced; newly synthesized, labeled hormone ranged between 0.6 and $12 \%$ of total labeled protein, and immunoreactive hormone ranged between 0.015 and $0.9 \%$ of total tissue protein. Effects of calcium on hormone biosynthesis, as determined by analyses of amounts of proparathyroid hormone in the tissues, were variable among tissues and in many cases were negligible. These results indicate that neoplastic and hyperplastic parathyroid tissues retain secretory responsiveness to changes in extracellular concentrations of calcium. Responses, however, are highly variable

Dr. Habener is an Investigator, Howard Hughes Medical Institute.

Received for publication 14 November 1977 and in revised form 6 April 1978. among different tissues, and in many instances are abnormal, inasmuch as greater than normal concentrations of calcium are required to alter release and synthesis of hormone. A combination of both increased mass of glandular tissue and abnormal regulations of hormone secretion appear to contribute to the hypersecretion of hyperparathyroidism.

\section{INTRODUCTION}

Primary hyperparathyroidism may be defined as a disorder characterized by a secretion of parathyroid hormone $(\mathrm{PTH})^{1}$ that is excessive and inappropriate for the level of serum calcium (1). This excess results in chronic hypercalcemia and hyperparathyroidism with the ensuing complications of renal stones, gastrointestinal and neuromuscular symptoms, and increased bone turnover. The disorder is invariably associated with enlargement of the parathyroid glands, usually as a neoplastic change (adenoma or carcinoma) in a single gland, although occasionally as a diffuse idiopathic hyperplasia of all glands (2). Clearly, some defect exists in the secretory responses of the neoplastic or hyperplastic glands that results in a decreased sensitivity to calcium, leading, in turn, to pathological alterations in a normally tightly controlled regulation of calcium homeostasis.

Two pathophysiologic mechanisms alone or in combination may be proposed to account for the excessive secretion of hormone in primary hyperparathyroidism. Either the mechanism controlling secretion is $(a)$ wholly or partly independent (autonomous) of the calcium concentration in the blood or is $(b)$ dependent (nonautonomous) on the calcium, but not until the concentration is higher than normal, i.e., a set-point error. Some information obtained from studies in normal ani-

\footnotetext{
${ }^{1}$ Abbreviations used in this paper: bPTH, bovine parathyroid hormone; $\mathrm{COOH}$, carboxy; hPTH, human parathyroid hormone; ProPTH, proparathyroid hormone; PSP, parathyroid secretory protein; PTH, parathyroid hormone; TCA, trichloroacetic acid; Tris-SDS, Tris-sodium dodecyl sulfate.
} 
mals is available in support of the former mechanism. In response to calcium, normal bovine parathyroid glands, studied in vitro $(3,4)$ and in vivo $(5)$, continued to secrete a small amount of hormone despite sustained hypercalcemia. In addition, these observations are further supported by the studies of Gittes and Radde, who have produced hypercalcemia in rats by the transplantation of multiple normal parathyroid glands (6). It was suggested that this calcium-insensitive component of secretion characteristic of normal cells may explain the excessive hormone production in hyperparathyroidism simply as a result of the greatly increased mass of parathyroid tissues. Thus, there would be no reason to postulate the existence of an abnormal responsiveness of the individual parathyroid cells to calcium (5).

It is difficult to obtain precise information regarding secretory responses in studies of patients with hyperparathyroidism in vivo, owing to the relatively low levels of hormone in the blood of many patients and to the problems resulting from the heterogeneity of the immunoreactive hormone in peripheral blood. Much of the circulating immunoreactive hormone in the blood of hyperparathyroid patients consists of hormonal fragments (7-11), some of which arise by metabolism of intact hormone after its secretion into the circulation $(11,12)$. Thus, changes in levels of immunoreactive hormone in peripheral blood in response to experimentally induced changes in the calcium concentration may not accurately reflect changes in rates of hormone secretion, particularly if calcium influences the rates of production of the fragments (13).

Some investigators reported that, with certain antisera, serum immunoreactive-PTH concentrations often do not fall during a calcium infusion administered to patients with parathyroid adenomas, whereas they do fall in patients with primary hyperplasia (14). Other investigators observed a suppression and a stimulation of serum PTH levels during infusions of calcium and EDTA, respectively, in all patients with hyperparathyroidism because of adenoma and hyperplasia alike (15). As suggested by Reiss and Canterbury (16), one explanation for these differences in results appears to be the variations in recognition of hormonal fragments in blood by different immunoassay systems.

Because of the difficulties in analyzing patterns of hormone secretion in vivo in patients with primary hyperparathyroidism we have conducted studies under in vitro conditions (17-19) with parathyroid tissues obtained surgically from patients with primary hyperparathyroidism.

\section{METHODS}

Preparation of hormone. Human parathyroid hormone [hPTH(1-84)] was prepared and provided by H. T. Keutmann (20). The fragments of human and bovine parathyroid hor- mone (bPTH), hPTH(1-34), [Tyr-34]bPTH(1-34), bPTH(25-48), -(44-68), -(1-13), and [Tyr-13]bPTH(1-13), and bovine proparathyroid hormone, minus 6 through plus 34 [bProPTH(-6-+34)], were all prepared by solid-phase chemical synthesis (21). The carboxy $(\mathrm{COOH})$-terminal peptides PTH(5384), bovine and human, were prepared by tryptic cleavage of maleoylated PTH (22). A mixture of peptides ${ }^{125}$ I-bPTH(34-84), -(37-84), and -(41-84) were prepared by gel filtration (Bio-Gel P-100, Bio-Rad Laboratories, Richmond, Calif.) of plasma obtained from a dog $30 \mathrm{~min}$ after the i.v. injection of ${ }^{125}$ I-bPTH (23). A modification of the chloramine-T method as described previously (24) was used for the preparation of the ${ }^{125} \mathrm{I}$-labeled peptides.

Preparation and incubation of tissues with radioactive amino acids. Portions of adenomas of the parathyroid glands, tissues from primary chief-cell hyperplasia of the parathyroid glands, and a pulmonary lesion that had metastasized from carcinoma of a parathyroid gland were obtained at the time of surgery. Bovine normal parathyroid glands were obtained from a local abattoir and human normal parathyroid glands were procured from autopsy material. All tissues were placed immediately in ice-cold Earle's Balanced Salt Solution. The human tissues were minced into $\approx 1$-mm pieces, and the bovine parathyroid glands were cut into slices of $0.5-1.0 \mathrm{~mm}$ in thickness. All tissues were rinsed once with cold Earle's Balanced Salt Solution. Human tissues, $50-100 \mathrm{mg}$, and $\approx 100$ $\mathrm{mg}$ of bovine gland slices were transferred to $30-\mathrm{ml}$ plastic flasks (Falcon Plastics, Div. of BioQuest, Oxnard, Calif.) containing $2 \mathrm{ml}$ of medium consisting of Eagle's Minimum Essential Medium obtained without glutamine, leucine, calcium, or magnesium (Grand Island Biological Co., Grand Island, N. Y.). The medium was supplemented with $5 \%$-fetalcalf serum, $2 \mathrm{mM}$ glutamine, $0.8 \mathrm{mM}$ magnesium chloride, and varying concentrations of calcium chloride (from 0.5 to $5.0 \mathrm{mM}$ ). Actual concentrations of calcium and magnesium ion in the medium were determined by flame photometry at the end of the incubations (25). Either $\left[4,5-{ }^{3} \mathrm{H}\right]$ leucine $(40-$ $60 \mathrm{Ci} / \mathrm{mmol}, 10-25 \mu \mathrm{Ci} / \mathrm{ml})$ or $\left[{ }^{14} \mathrm{C}\right]$ leucine $(280 \mathrm{Ci} / \mathrm{mmol}$, $5 \mathrm{mCi} / \mathrm{ml}$, New England Nuclear, Boston, Mass.) was added to the medium. The flasks containing tissues and media were flushed with a mixture of $5 \% \mathrm{CO}_{2}$ and $95 \%$ air, and were incubated with gentle shaking at $37^{\circ} \mathrm{C}$ for $4 \mathrm{~h}$. In some experiments, additional incubations were performed with $\left[{ }^{14} \mathrm{C}\right]$ leucine for $4 \mathrm{~h}$ followed by a 30-min "pulse labeling" with $\left[{ }^{3} \mathrm{H}\right]$ leucine to selectively label newly synthesized ProPTH and PTH and allow a more direct assessment of the effects of the variable calcium concentration on the rates of hormone biosynthesis (19). At the end of the incubation period, the contents of the flasks were transferred to conical centrifuge tubes, and cells and tissues (much of the human parathyroid tissue had dissociated into individual cells and clumps of cells during the incubations) were separated from the medium by centrifugation at $600 \mathrm{~g}$ for $5 \mathrm{~min}$.

Preparation of extracts of tissues and media. The tissues were homogenized in $1-2 \mathrm{ml}$ of $8 \mathrm{M}$ urea- $0.2 \mathrm{~N} \mathrm{HCl}$ with a glass/Teflon homogenizer. The homogenates were clarified by centrifugation at $10,000 \mathrm{~g}$ for $10 \mathrm{~min}$. Proteins were precipitated from the resultant supernates by addition of $5 \mathrm{vol}$ of cold $12 \%$ trichloroacetic acid (TCA), and the precipitates were collected by centrifugation. The acid-insoluble precipitates were dissolved in $0.2 \mathrm{~N} \mathrm{NaOH}$ and again precipitated in cold TCA. The final precipitates were suspended in $2 \mathrm{ml}$ of water, lyophilized to dryness, and extracted in $1 \mathrm{ml}$ of $8 \mathrm{M}$ urea$0.15 \mathrm{~N}$ acetic acid. Radiolabeled proteins in the media were isolated by precipitation twice in cold 10\% TCA and solubilization in $0.2 \mathrm{~N} \mathrm{NaOH}$. The final lyophilized precipitates were extracted with $1 \mathrm{ml}$ of $8 \mathrm{M}$ urea-0.15 $\mathrm{N}$ acetic acid. Amounts of the total acid-insoluble radioactive proteins in $10-25-\mu l$ 
aliquots of the urea-acid extracts were determined by precipitation in $1 \mathrm{ml}$ of $10 \%$ TCA in the presence of $200 \mu \mathrm{g}$ of bovine serum albumin, collection of the precipitates by filtration on Whatman GF/C glass-fiber pads (Whatman, Inc., Clifton, N. J.), and assay in a scintillation spectrometer by a toluene-based scintillation fluid (Liquifluor, New England Nuclear, Boston, Mass.).

Electrophoretic analysis of radiolabeled proteins. Aliquots of 100-150 $\mu \mathrm{l}$ of the acid-urea extracts of the parathyroid tissues and media were subjected to electrophoresis on discontinuous $10 \%$ polyacrylamide gels containing $8 \mathrm{M}$ urea and $0.1 \mathrm{M}$ potassium acetate ( $\mathrm{pH} 4.4-4.8$ ) (urea-acetate gels) as described previously (26). In addition, certain of the extracts were analyzed by electrophoresis on discontinuous $15 \%$ polyacrylamide gels that contained $0.1 \%$ sodium dodecyl sulfate and $0.375 \mathrm{~m}$ Tris at $\mathrm{pH} 8.8$ (Tris-SDS gels) (27). The acid-urea extracts were first adjusted to $\mathrm{pH}$.6.8 with Tris base, made to $2 \%$ in SDS, $5 \%$ 2-mercaptoethanol, and heated for $3 \mathrm{~min}$ at $100^{\circ} \mathrm{C}$. In those experiments in which the tissues had been incubated with $\left[{ }^{3} \mathrm{H}\right]$ leucine for periods of $4 \mathrm{~h}, 1,000$ $2,000 \mathrm{cpm}$ of $\left[{ }^{14} \mathrm{C}\right]$ leucine-labeled bPTH and parathyroid secretory protein (PSP) were added to the aliquots of tissues and media that had been incubated in the lowest $(0.5 \mathrm{mM})$ and highest $(5.0 \mathrm{mM})$ concentrations of calcium to serve as electrophoretic markers. No radioactive markers were used in those experiments in which tissues had been incubated for 4 $\mathrm{h}$ with $\left[{ }^{14} \mathrm{C}\right]$ leucine followed by a 30 -min pulse label with $\left[{ }^{3} \mathrm{H}\right]$ leucine.

At the completion of the electrophoretic procedures, 1-mm slices of the gels were prepared, and the radioactivity was measured by scintillation spectroscopy after the proteins had been extracted from the gels in a mixture of water, toluene, and NCS tissue solubilizer (Amersham/Searle Corp., Arlington Heights, Ill.) as described previously (26). In many of the experiments, duplicate polyacrylamide gels were prepared for selected aliquots of tissues and media. The duplicate gels also were sliced, but the proteins in the gel slices were extracted either in $0.2 \mathrm{ml}$ of $0.05 \mathrm{M}$ sodium barbital (pH 8.5), $10 \%$ plasma, by gentle shaking for $12-14 \mathrm{~h}$ at $4^{\circ} \mathrm{C}$ (urea-acetate gels) or in $5.0 \mathrm{mM}$ Tris (pH 8.8), $0.1 \%$ SDS,
$1 \mathrm{mM}$ phenylmethylsulfonyl fluoride for $12-14 \mathrm{~h}$ at $25^{\circ} \mathrm{C}$ (Tris-SDS gels). The radioactivity in the 25-50- $\mu$ l aliquots of the extracts of gel slices was measured by scintillation spectroscopy in Insta-Gel (Packard Instrument Co., Downers Grove, Ill.). Recoveries of labeled proteins in the extracts were from 77 to $115 \%$. Immunoreactive PTH also was measured in 1020- $\mu$ l aliquots of the gel-slice extracts to correlate amounts of radioactivity with immunoreactivity. Recoveries of immunoreactivity in the extracts were from 68 to $122 \%$. The electrophoretic gels were calibrated on several occasions by electrophoresis of the iodinated fragments of bPTH, [Tyr-34]bPTH(1-34), bPTH(34-84), bPTH(25-48), and bPTH(44-68).

Radioimmunoassays of PTH and ProPTH. Aliquots of the urea-acid extracts of the parathyroid tissues and the incubation media and of gel-slice extracts were assayed in multiple dilutions (5-20 $\mu \mathrm{l})$ with radioimmunoassays for PTH and for ProPTH under conditions described previously $(24,28)$. Both antisera GP-1 (1:200,000) and GP-133 (1:25,000) were routinely employed in the assay of PTH. In addition, extracts of slices prepared from the Tris-SDS gels were assayed with antiserum R-4 (1:5,000) prepared by the immunization of a rabbit with synthetic bPTH(1-34). This antiserum was provided by G. P. Mayer. Standard solutions consisted of native hPTH (20) and synthetic human ProPTH(-6-+34) (28).

Determination of solubility of radioiodinated hormonal peptides in TCA. Several parathyroid hormonal peptides were radioiodinated with ${ }^{125} \mathrm{I}$. Peptides, $50,000-200,000 \mathrm{cpm}$, were added to extracts ( $8 \mathrm{M}$ urea, $0.2 \mathrm{~N} \mathrm{HCl}$ ) of adenoma tissue and to Eagle's Minimum Essential Medium containing $5 \%$ calf serum (incubation medium) and were treated with 7.5 and $12.5 \%$ TCA under conditions identical with those used to extract radiolabeled and immunoreactive proteins from parathyroid tissues and media. The radioactivity in the final acid-insoluble precipitates and all supernates was measured in a gamma well spectrometer.

Determinations of the stability of radiolabeled PTH in incubation media. In several of the experiments, additional aliquots of the parathyroid tissues were incubated in medium containing a calcium concentration of either $0.5 \mathrm{mM}$ or 5.0 $\mathrm{mM}$ to which was added $50 \mu \mathrm{l}$ of a mixture of $\left.{ }^{35} \mathrm{~S}\right]$ methionine-

TABLE I

Tissues from Patients with Primary Hyperparathyroidism

\begin{tabular}{|c|c|c|c|c|c|c|c|}
\hline \multirow{2}{*}{$\begin{array}{c}\text { Tissue } \\
\text { preparation }\end{array}$} & \multirow[b]{2}{*}{ Age } & \multirow[b]{2}{*}{ Sex } & \multicolumn{2}{|c|}{ Serum calcium } & \multicolumn{2}{|c|}{ Plasma PTH } & \multirow{2}{*}{$\begin{array}{l}\text { Weight of } \\
\text { tissue excised }\end{array}$} \\
\hline & & & mean & range & mean & range & \\
\hline & $y r$ & & \multicolumn{2}{|r|}{$m g / d l$} & \multicolumn{2}{|c|}{$\mu l$-equiv* } & $g$ \\
\hline \multicolumn{8}{|l|}{ Adenoma } \\
\hline 1 & 65 & $\mathbf{M}$ & 11.0 & $10.7-11.6$ & 24 & $23-24$ & 2.5 \\
\hline 2 & 54 & $\mathbf{F}$ & 11.9 & $11.4-12.5$ & 16 & $15-16$ & 3.0 \\
\hline 3 & 52 & $\mathbf{F}$ & 12.5 & $12.2-12.7$ & 14 & $12-16$ & 2.5 \\
\hline 4 & 48 & $\mathbf{F}$ & 11.2 & $10.7-11.5$ & 13 & $12-15$ & 1.0 \\
\hline 5 & 68 & $\mathbf{M}$ & 13.6 & $12.3-15.0$ & \multicolumn{2}{|c|}{$>150$} & 2.0 \\
\hline 6 & 37 & $\mathbf{F}$ & 11.9 & $11.8-12.2$ & 19 & $16-22$ & 3.0 \\
\hline \multicolumn{8}{|c|}{$\begin{array}{l}\text { Chief-cell } \\
\text { hyperplasia }\end{array}$} \\
\hline 1 & 47 & $\mathbf{M}$ & 13.0 & $12.7-13.5$ & 39 & $23-80$ & 8.0 \\
\hline 2 & 22 & $\mathbf{F}$ & 11.2 & $10.7-12.1$ & 18 & $15-20$ & 1.5 \\
\hline \multicolumn{8}{|l|}{ Carcinoma } \\
\hline 1 & 24 & $\mathbf{F}$ & 11.2 & $10.8-12.2$ & 12 & $6-20$ & 2.5 \\
\hline
\end{tabular}

* Microliter-equivalents of hyperparathyroid plasma are used as the standard in the radioimmunoassay for PTH (normal range, 2-10). 


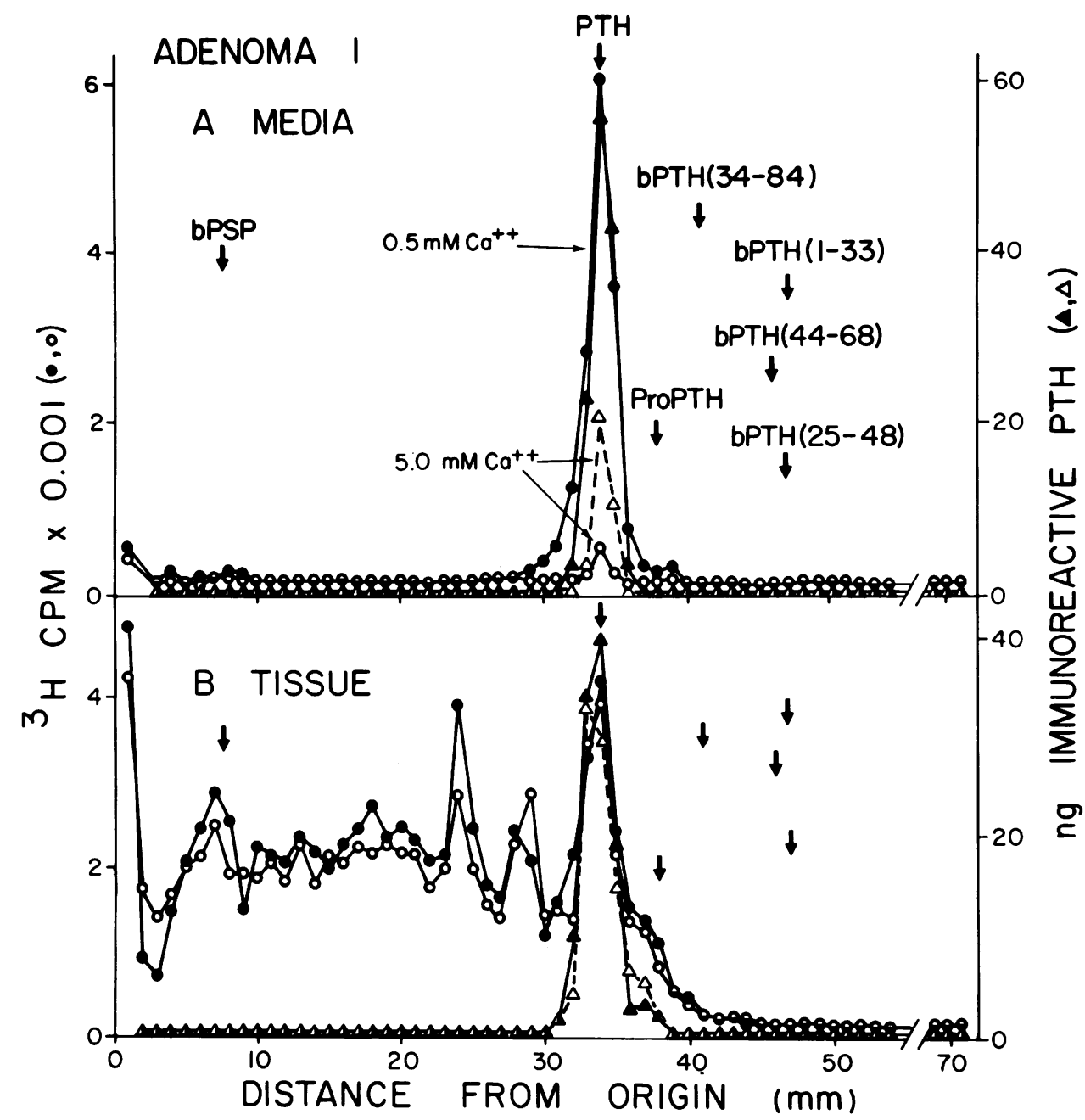

FIGURE 1 Urea-acetate gel electrophoresis of labeled proteins and immunoreactive PTH in extracts of (A) media and (B) tissues prepared from parathyroid adenoma no. 1 after incubations with $\left[{ }^{3} \mathrm{H}\right.$ ]leucine for $4 \mathrm{~h}$ in $0.5 \mathrm{mM}$ calcium $(O, \Delta)$ or $5.0 \mathrm{mM}$ calcium $(O, \Delta)$. Immunoreactivity was determined with antiserum GP-1 $(1: 200,000)$. The following abbreviations are used throughout: bPSP, bovine parathyroid secretory protein; bPTH(1-33), synthetic bovine PTH (fragment, the usual sequence of residues 1-33 and, for the 34th residue, tyrosine substituted for phenylalanine; bPTH(34-84), a mixture of COOH-terminal fragment of bovine PTH: $34-84(40 \%)$, 37-84 (50\%), and 41-84 (10\%).

PTH and PSP that had been prepared by incubation of parathyroid tissues for $3 \mathrm{~h}$ in medium containing $\left.{ }^{35} \mathrm{~S}\right]-$ methionine (460 Ci/mmol, $0.5 \mathrm{mCi} / \mathrm{ml}$, Amersham $/$ Searle). Amounts of $\left[{ }^{35}\right.$ S]methionine-PTH and PSP in the medium both before and after the incubation were assessed by polyacrylamide gel electrophoresis.

\section{RESULTS}

Several of the clinical data relevant to the status of calcium metabolism in the nine patients whose parathyroid tissues were analyzed in this study are listed in Table I. In general, the patients with the most severe hyperparathyroidism (highest serum calcium and plasma immunoreactive-PTH values) proved to have the largest masses of parathyroid tissue at surgery.
The secretory and biosynthetic responses of the parathyroid tissues obtained from these nine patients were evaluated quantitatively in vitro as a function of the extracellular calcium concentrations. Amounts of newly synthesized hormone released into the medium and stored in the tissue were determined by measuring the amounts of $\left[{ }^{3} \mathrm{H}\right]$ leucine-PTH obtained upon electrophoresis of radioactive proteins in extracts of the incubation media and in the parathyroid tissues. Immunoreactive PTH in extracts prepared from the gel slices was also measured by radioimmunoassay. Representative electrophoretic patterns (urea-acetate gels) are shown for two of the parathyroid adenomas (Figs. 1 and 2), one of the two primary chief-cell hyper- 
A MEDIA

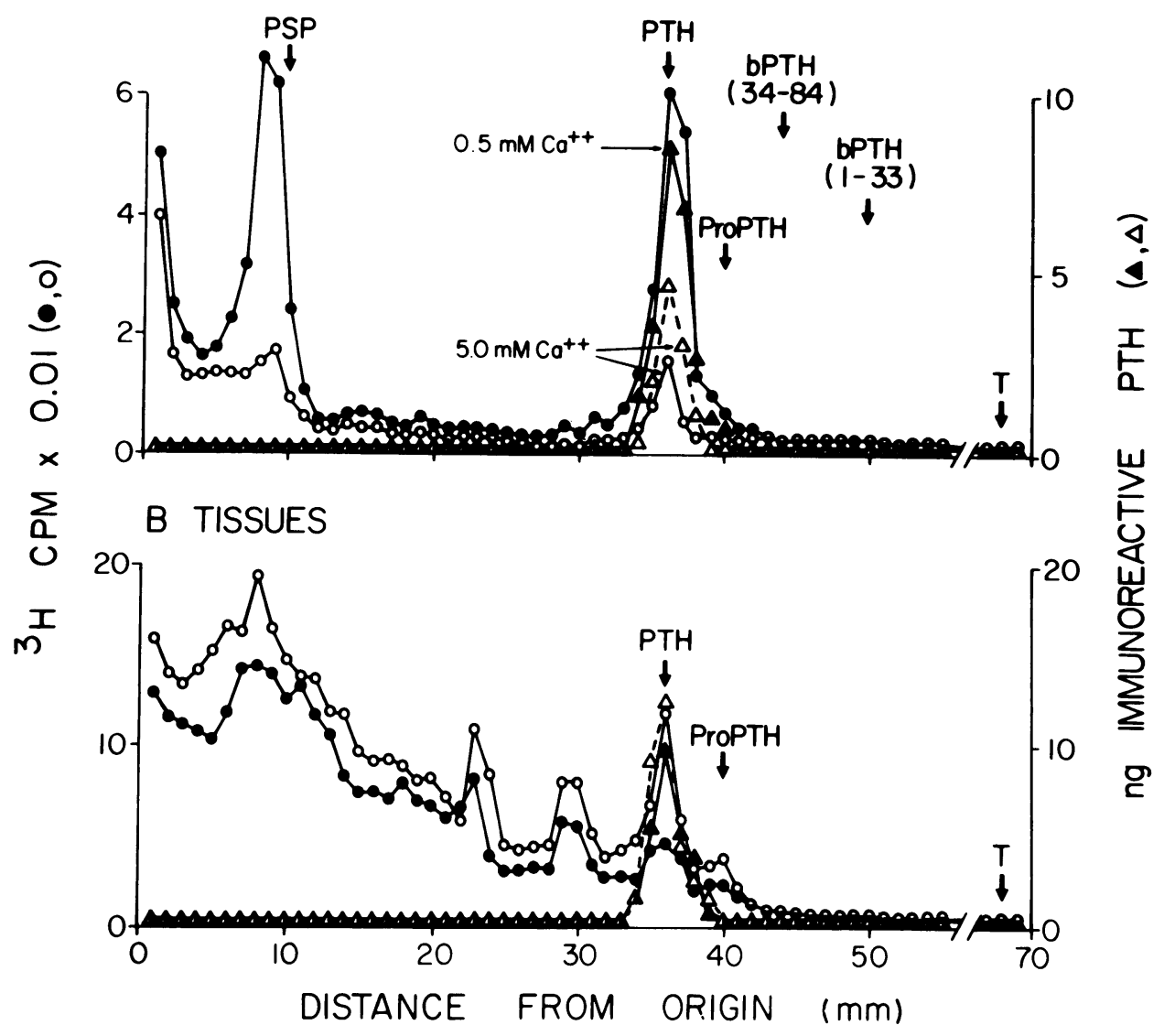

FIGURE 2 Urea-acetate gel electrophoresis of labeled proteins and immunoreactive PTH in extracts of (A) media and (B) tissues after a 4-h incubation of adenoma no. 6 with $\left[{ }^{3} \mathrm{H}\right]$ leucine. See legend to Fig. 1 for abbreviations. T represents methyl-green dye.

plasias (Fig. 3), and the carcinoma (Fig. 4). For each of these tissues only the electrophoretic patterns are shown that correspond to the incubations carried out in concentrations of calcium that produced the maximum stimulation and suppression of hormone release. Each tissue, however, was similarly studied under conditions of from four to six different concentrations of calcium.

A clearly discernible peak of radioactivity that migrated coincidentally with the peak of immunoreactive PTH was seen in every analysis. Somewhat surprising, however, was the finding that two of the six adenomas (nos. 1 and 3) and one of the two hyperplastic tissues (no. 1) released little if any parathyroid secretory protein (PSP) (e.g., see Fig. 1). Parathyroid secretory protein is a protein of unknown biological function with a mol wt of 150,000 (two 70,000-mol-wt subunits) produced and secreted by parathyroid tissue (29). Likewise, no discrete peak corresponding to PSP was seen in the media obtained from the incubation of the carcinoma (Fig. 4). All other tissues showed amounts of PSP in the media that were comparable with those found upon incubations of normal bovine glands (29).

The urea-acetate gels were calibrated by parallel analyses of radioiodinated PTH fragments consisting of a mixture of the $\mathrm{COOH}$-terminal fragment 34-84, $37-84$, and 41-84 that appears in the circulation of dogs given ${ }^{125} \mathrm{I}-\mathrm{PTH}$ intravenously, and the $\mathrm{NH}_{2}$-terminal fragment 1-34 prepared by chemical synthesis. The predominant immunoreactive material observed in all of the electrophoretic studies corresponded in mobility to PTH. In the extracts of the tissues, a small amount of reactivity was observed at the position of ProPTH; little immunoreactivity was found at the positions of the PTH fragments. Inasmuch as the antiserum to PTH crossreacts to the extent of $30 \%$ with ProPTH, it is likely that this additional component of immunoreactivity in the tissue extracts detected by the immuno- 


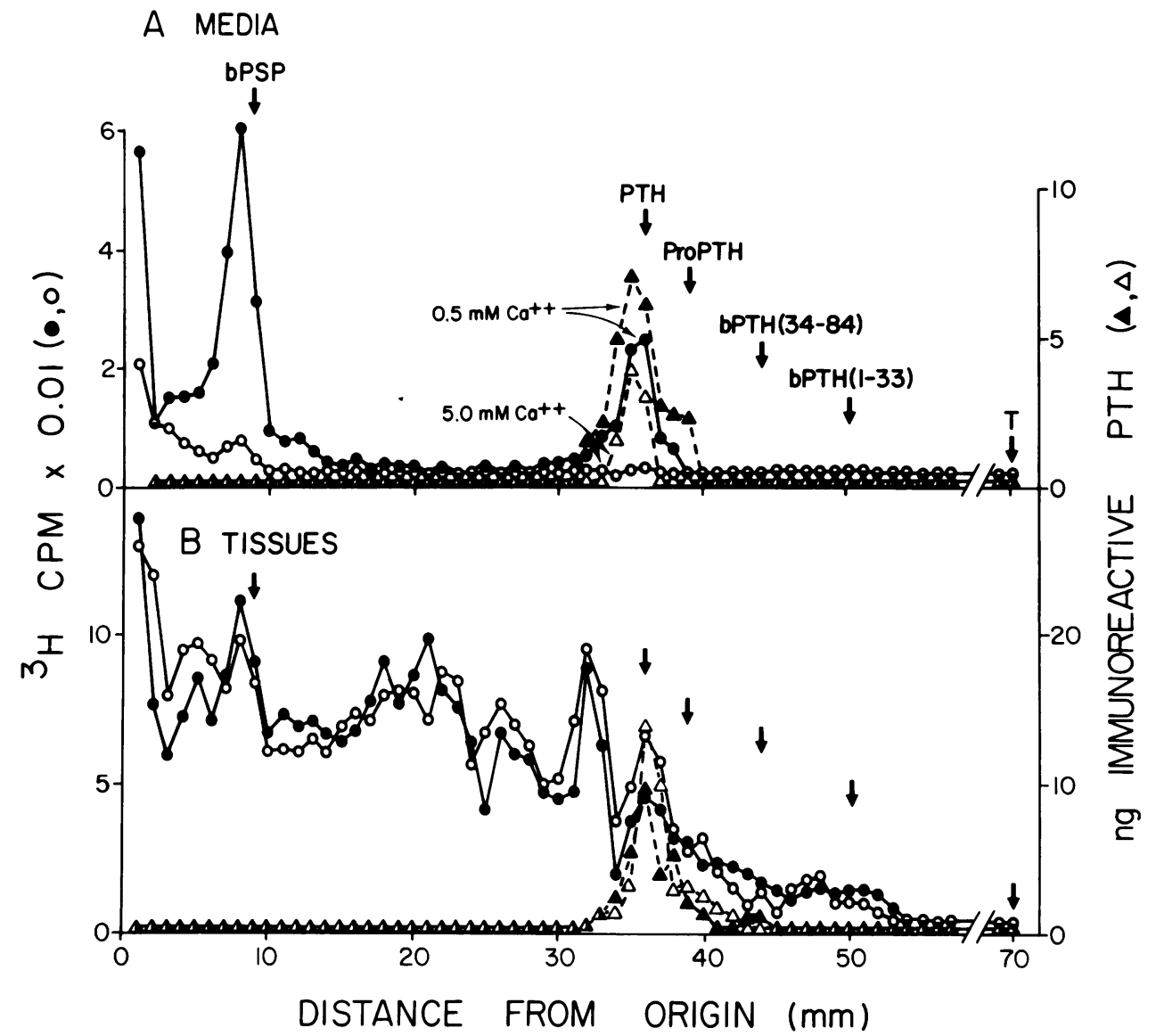

FIGURE 3 Urea-acetate gel electrophoresis of labeled proteins and immunoreactive PTH in extracts of (A) media and (B) tissues of chief-cell hyperplasia no. 2 after incubation for $4 \mathrm{~h}$ with $\left[{ }^{3} \mathrm{H}\right]$ leucine. See legend to Fig. 1 for abbreviations.

assay for PTH consists of ProPTH (28). In certain of the media, some, albeit small, amounts of immunoreactivity were seen in the region of the urea-acetate gels corresponding to PTH fragments (Figs. 3 and 4), whereas other media extracts did not contain any detectable immunoreactivity other than that corresponding to PTH (Figs. 1 and 2).

To analyze the character of the hormone in the samples more extensively certain extracts were examined further by a second physico-chemical means of separating the proteins: electrophoresis in Tris-SDS gels where separations of proteins are achieved on the basis of molecular weights. In addition, immunoreactivity in fractions prepared from the Tris-SDS gels was assayed simultaneously by both $\mathrm{NH}_{2}$-terminal and $\mathrm{COOH}$-terminal antisera. Figs. 5 and 6 show the results of these additional analyses of extracts of media and tissues prepared from adenomas 3 (Fig. 5) and 4 (Fig. 6 ). The results are qualitatively similar to those obtained from analyses with the urea-acetate gels; the predominant immunoreactive species corresponds to intact hormone, but there are also smaller species present. It should be noted that the amounts of $\mathrm{NH}_{2}$-reactive fragments are probably exaggerated with respect to amounts of intact hormone because the $\mathrm{NH}_{2}$-terminal antiserum (R-4) is approximately three times more sensitive for detection of hPTH(1-34) compared to hPTH$(1-84){ }^{2}$ Inasmuch as the structural compositions of the fragments are unknown, and therefore no assay standards for the fragments are available, it is not possible to accurately estimate absolute amounts of fragments. The actual amounts of fragments, if they were known, may be more or less than those indicated in the analyses.

Summaries of the amounts or radioactive PTH in the tissues and media, assessed by measurement of the amounts of radioactivity contained in the peaks from the polyacrylamide gels that corresponded in mobilities to PTH, are shown in Figs. 7 and 8; Fig. 7 shows

\footnotetext{
${ }^{2}$ Unpublished observations.
} 


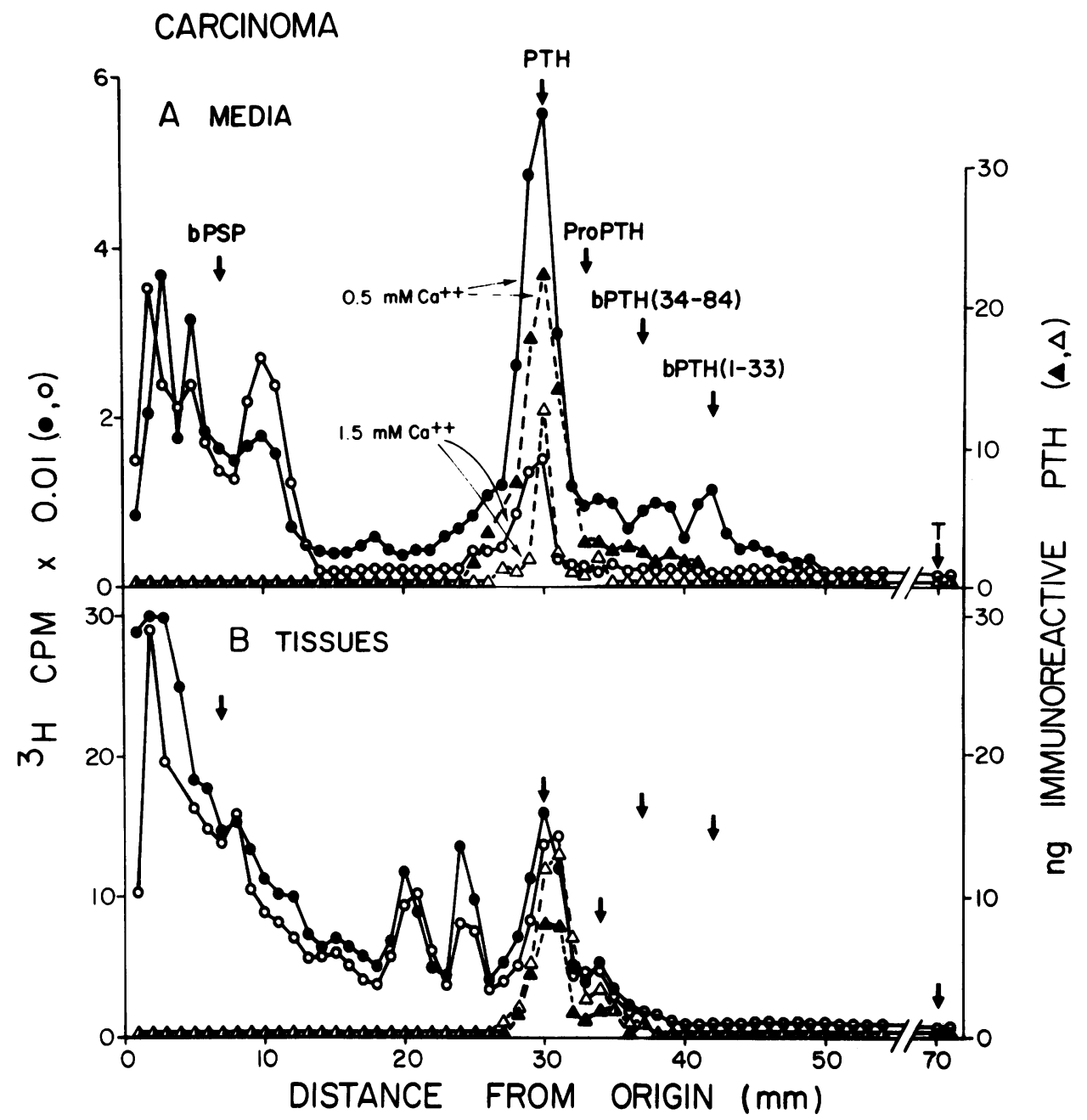

FIgURE 4 Urea-acetate gel electrophoresis of labeled proteins and immunoreactive PTH in extracts prepared from parathyroid carcinoma tissues incubated for $4 \mathrm{~h}$ with $\left[{ }^{3} \mathrm{H}\right]$ leucine. Calcium concentrations are indicated. See legend to Fig. 1 for abbreviations.

the amounts of newly synthesized PTH expressed as a percent of the total amounts of nonhormonal, acidinsoluble, radioactive protein synthesized during the incubations (Table II). Fig. 8 indicates the changes in amounts of radiolabeled PTH relative to conditions of maximum glandular stimulation in $0.5 \mathrm{mM}$ of calcium. Fig. 8 also shows the secretory response of three normal human parathyroid glands obtained during autopsies. The data on normal human glands are limited because of difficulties in obtaining fresh, viable tissue, but the responses are similar to those of normal bovine glands.

The responses of the parathyroid tissues to calcium were further analyzed by radioimmunoassay of the amounts of immunoreactive PTH contained in the urea-acid extracts of the tissues and media (Table III). We have previously described the dynamics of hor- mone secretion and storage in response to calcium in normal bovine glands (19). These data obtained from normal bovine parathyroid tissues are shown in Tables II and III for comparison with the parathyroid tumor tissues. The relative amounts of immunoreactive hormone contained in the individual tissues, expressed as nanograms of hormone per milligram of tissue protein, varied greatly among the different tissues (28$8,100 \mathrm{ng}$ PTH/mg tissue protein) as did the relative distributions of hormone between tissues and media (Table III); for example, compare the response of adenoma no. 3 with that of adenoma no. 4.

All of the parathyroid tissues studied responded to changes in extracellular calcium. Increasing the concentrations of calcium resulted in a fall in the amounts of both radioactive and immunoreactive PTH released into the media and, in most but not all instances, to 


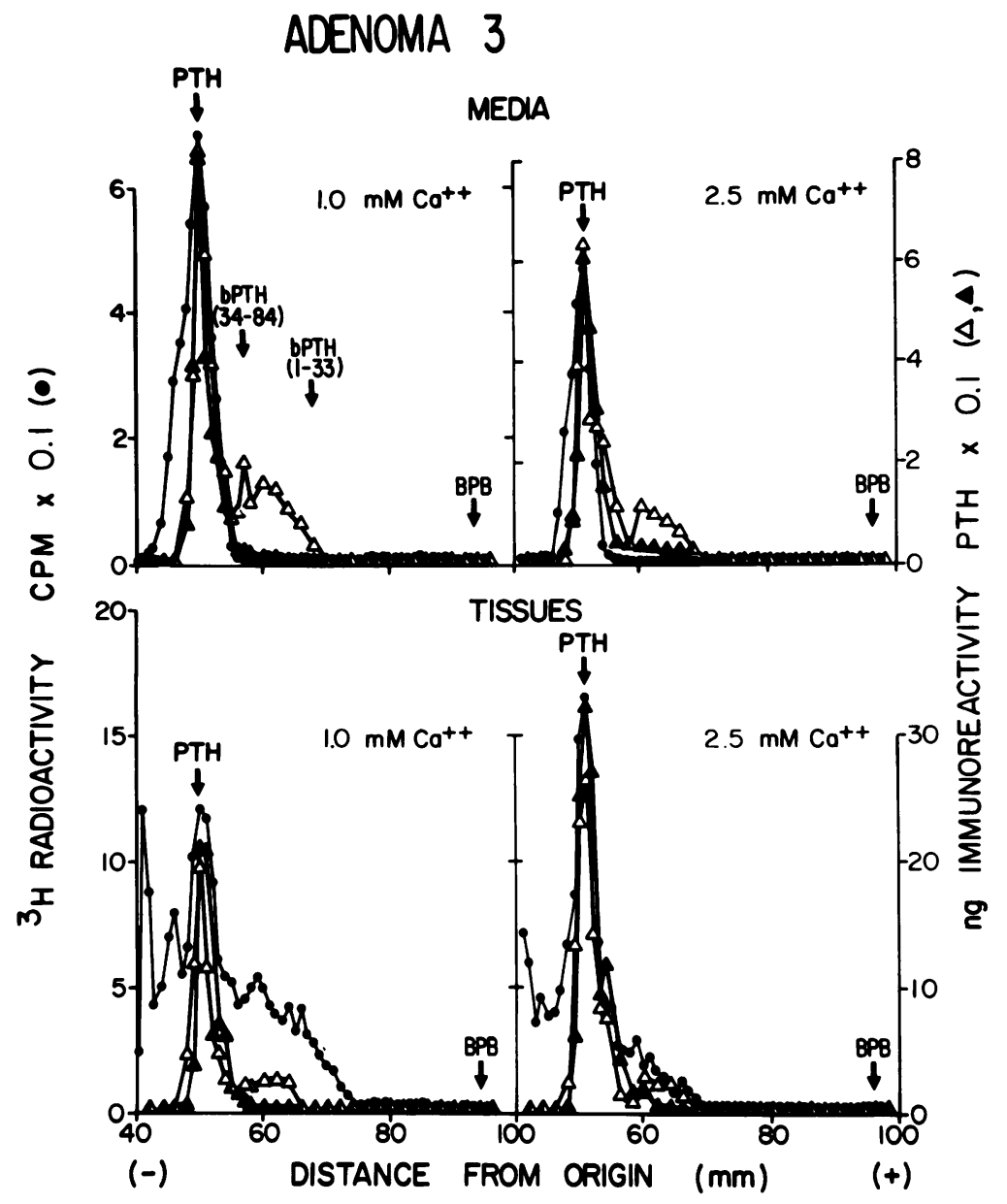

FIgURE 5 Tris-SDS gel electrophoresis of labeled proteins and immunoreactive PTH in extracts of media (upper panels) and tissues (lower panels) of adenoma no. 3 after incubation for $4 \mathrm{~h}$ with $\left[{ }^{3} \mathrm{H}\right]$ leucine and indicated concentrations of calcium. (O), ${ }^{3} \mathrm{H}$-radioactivity; ( $\triangle$ ), COOHterminal immunoreactivity (antiserum GP-1, 1:200,000); $\triangle$ ), $\mathrm{NH}_{2}$-terminal immunoreactivity (antiserum R-4, 1:5000); BPB, bromphenol-blue marker; bPTH(34-84), mixture of fragments 3484, 37-84, and 41-84; bPTH(1-33), synthetic fragment bPTH(1-33) plus tyrosine substituted at 34 .

a corresponding increase in the amounts of hormone stored within the tissues. Although every tissue studied responded to some degree to changes in concentrations of calcium, both the magnitude of the response and the amounts of calcium required to elicit a given secretory response varied considerably. For example, adenomas no. 1 and no. 3 and perhaps the carcinoma were as sensitive to calcium as were the normal bovine and human glands, whereas the other four adenomas and the two hyperplastic tissues required substantially higher concentrations of calcium to produce comparable suppression of hormone release (Figs. 7 and 8).

In some of the tissues, the increase in the storage of PTH as the release of PTH in response to calcium decreased was marked, e.g., adenoma no. 5 (Figs. 7 and 8). The increased storage of PTH compensated for the decrease in hormone secretion so that the total amounts of PTH in the tissue and medium together remained relatively constant. In other tissues, however, including the normal bovine glands, a decrease in the total of hormone in the tissues and media was observed.

We showed previously in studies of hormone synthesis and secretion in bovine parathyroid glands that the decrease in total PTH is the result of a combination of both decreased rates of biosynthesis and increased intracellular degradation of hormone (19). For more-direct tests of the effects of calcium on the biosynthesis of hormone, we additionally analyzed several of the tissues for amounts of ProPTH, the immediate biosynthetic precursor of PTH, with both pulse labeling techniques and specific radioimmunoassay. Inasmuch as 


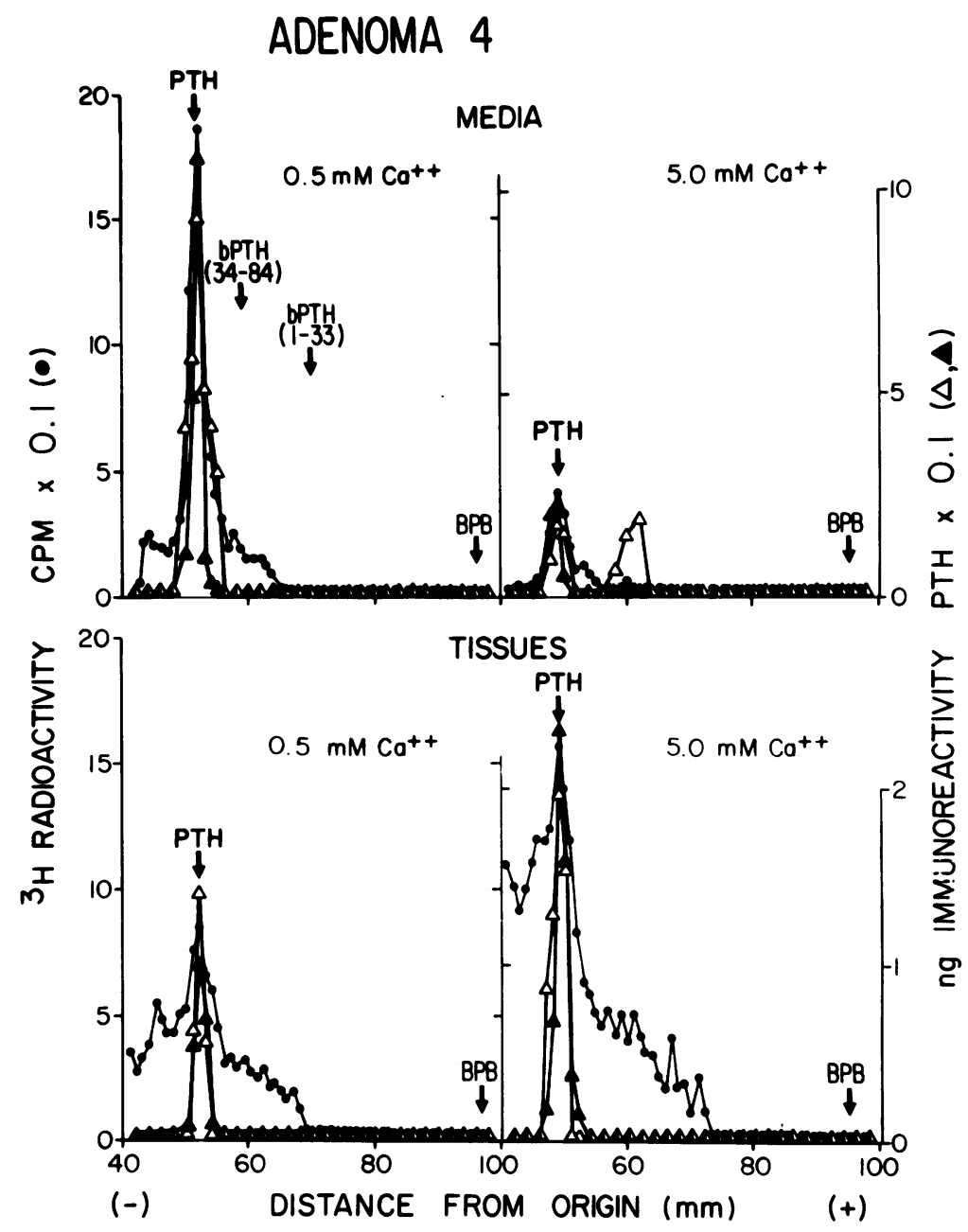

FIGURE 6 Tris-SDS gel electrophoresis of labeled proteins and immunoreactive PTH in extracts of media (upper panels) and tissues (lower panels) of adenoma no. 4 after incubation for $4 \mathrm{~h}$ with $\left[{ }^{3} \mathrm{H}\right]$ leucine and indicated concentrations of calcium.

PTH arises during biosynthesis via proteolytic cleavage from ProPTH $(30,31)$, direct evaluations of amounts of ProPTH in the tissues provide a more valid measure of hormone synthesis than do evaluations of amounts of PTH (19). Fig. 9 shows the results from gel electrophoresis of two of the parathyroid tissues that were pulse labeled with $\left[{ }^{3} \mathrm{H}\right]$ leucine for $30 \mathrm{~min}$ after 4-h incubation in $\left[{ }^{14} \mathrm{C}\right]$ leucine and with low and high concentrations of calcium in the media. In Table IV are the results of radioimmunoassay measurements of amounts of immunoreactive ProPTH in extracts of several of the tissues, including normal bovine parathyroid glands, for comparison with the neoplastic and hyperplastic tissues. Although increasing the concentrations of calcium decreased the amounts of both newly synthesized (Fig. 9) and total cellular ProPTH (Table IV) to some degree, the effects were not striking and were not sufficient to account for the decrease in the total of PTH (tissue plus media) seen, for example, in studies of adenoma no. 1 . These results indicate that under conditions of high calcium concentrations, a substantial fraction of the PTH synthesized is neither secreted from nor stored in the parathyroid tissue and suggest that the hormone may be degraded within the tissue in a manner analogous to that observed during studies of bovine parathyroid glands (19).

To investigate the possibility that some of the PTH released into the media during the incubations of tissues may undergo degradation while in the media by a calcium-dependent process, which, not being recognized, would give spurious results with regard to the effects of calcium on the secretion of hormone, $\left[{ }^{35} \mathrm{~S}\right]-$ methionine-PTH previously isolated by electrophoresis on polyacrylamide gels was incubated with ade- 


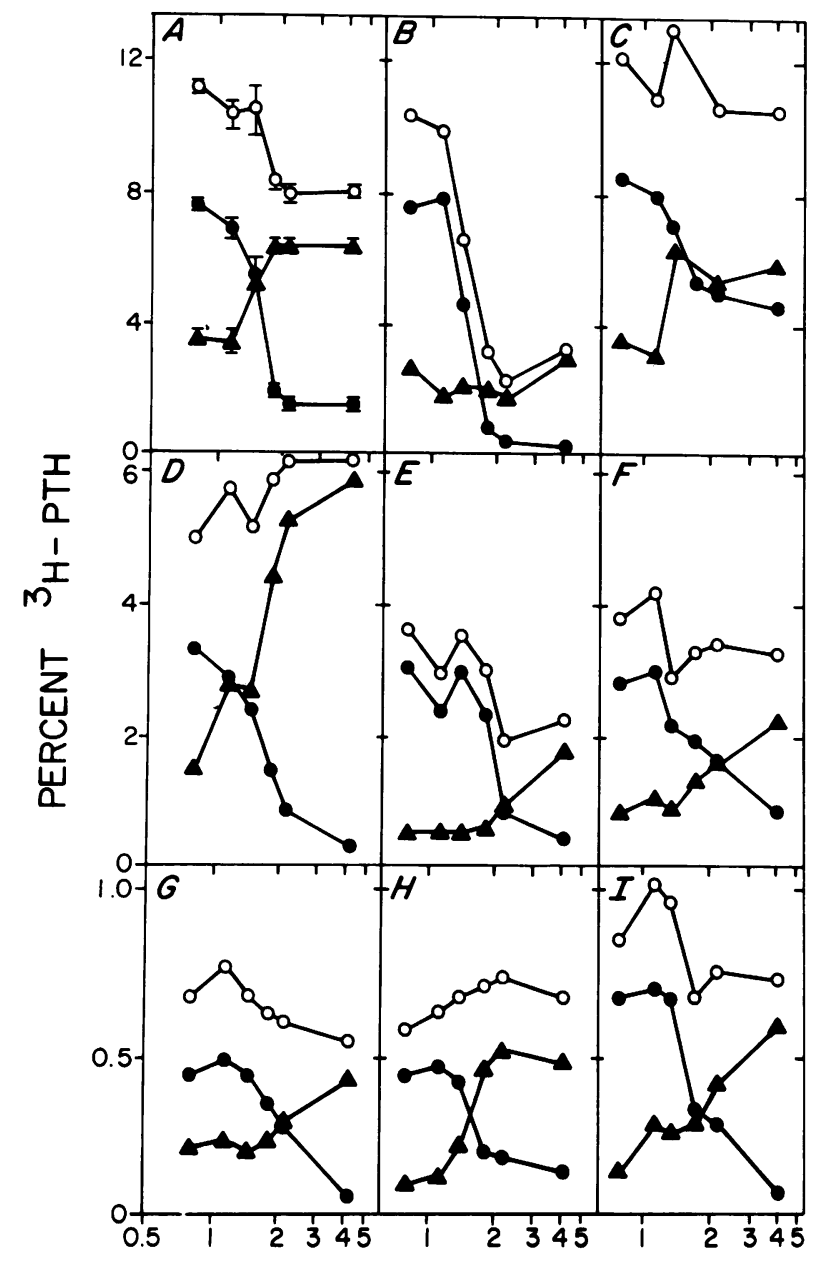

\section{CONCENTRATION of CALCIUM (mM)}

FIGURE 7 Responses of neoplastic and hyperplastic parathyroid tissues to different concentrations of calcium during 4-h incubations of tissues with $\left[{ }^{3} \mathrm{H}\right]$ leucine. Amounts of ${ }^{3} \mathrm{H}$-PTH were determined by polyacrylamide gel electrophoresis and are expressed as percent of the total acid-insoluble radioactivity minus the ${ }^{3} \mathrm{H}-\mathrm{PTH} .{ }^{3} \mathrm{H}-\mathrm{PTH}$ in media, (O); tissues, $(\Delta)$; media plus tissues, $(\mathrm{O})$. A, bovine parathyroid tissues; $\mathrm{B}$, adenoma no. 1; C, adenoma no. 2; D, adenoma no. 3; E, adenoma no. $4 ; \mathrm{F}$, adenoma no. 5 ; $\mathrm{G}$, adenoma no. 6 ; $\mathrm{H}$, chief-cell hyperplasia no. 1; I, chief-cell hyperplasia no. 2.

noma tissues and $\left[{ }^{3} \mathrm{H}\right]$ leucine in $0.5 \mathrm{mM}$ and $5.0 \mathrm{mM}$ calcium, respectively, in two experiments (adenoma no. 1 and hyperplasia no. 2). Calculations of the recoveries of the $\left[{ }^{35} \mathrm{~S}\right]$ methionine-PTH when extracts of the media were analyzed by gel electrophoresis were 68 and $72 \%$ (adenoma no. 1) and 81 and $73 \%$ (hyperplasia no. 2) for incubation in 0.5 and $5.0 \mathrm{mM}$ calcium, respectively. Thus, no selective effect of calcium on the recovery of PTH from the incubation media was found.

In view of the recent reports that parathyroid adenomas contain (32) and secrete (33) large amounts of
immunoreactive-PTH fragments and that these fragments remain soluble when treated with TCA (32), several peptide fragments of PTH available in the laboratory were radioiodinated with ${ }^{125}$ I. Acid-precipitable radioactive protein was measured for each of the fragments after their addition to incubation media and to urea-acid extracts of adenoma tissue as described in Methods. Nearly all of the PTH fragments were readily recovered by acid precipitation (Table V). The exceptions were the hydrophilic peptide bPTH(44-68), of which only $30 \%$ could be recovered in the acid precipitate, and the small peptides bPTH(1-13) and [Tyr13]bPTH(1-13), of which only $50-60 \%$ was recovered.

\section{DISCUSSION}

The results of these studies indicate that the secretion and synthesis of PTH by neoplastic and hyperplastic parathyroid tissues are responsive to calcium when studied in vitro. It seems reasonable to conclude that a similar responsiveness of these tissues to extracellular-fluid calcium exists in vivo. Thus, neoplastic and(or) hyperplastic transformation of the parathyroid tissue does not necessarily lead to an autonomous state of PTH secretion in which all sensitivity to calcium is lost.

These findings in vitro are consistent with previous reports derived from studies in vivo of the effects

\section{TABLE II}

Effects of Calcium on the Distribution of Total Acid-Insoluble Radioactive Proteins (cpm $\times 0.001)^{*}$ in Parathyroid Tissues and in Media after a 4-h Incubation of Parathyroid Tissues with $\left[{ }^{3} \mathrm{H}\right]$ Leucine

\begin{tabular}{|c|c|c|c|c|c|c|}
\hline \multirow{2}{*}{$\begin{array}{l}\text { Tissue } \\
\text { preparation }\end{array}$} & \multicolumn{3}{|c|}{ Mediat } & \multicolumn{3}{|c|}{ Tissues $\downarrow$} \\
\hline & 1.0 & 5.0 & change & 1.0 & 5.0 & change \\
\hline & & & $\%$ & & & $\%$ \\
\hline $\begin{array}{l}\text { Normal glands } \\
\text { (bovine) }\end{array}$ & 398 & 82.0 & -79 & 1,200 & 1,080 & -10 \\
\hline \multicolumn{7}{|l|}{ Adenomas } \\
\hline 1 & 35.9 & 4.3 & -88 & 648 & 642 & -1 \\
\hline 2 & 15.9 & 7.2 & -55 & 80.1 & 67.8 & -15 \\
\hline 3 & 18.0 & 9.8 & -46 & 135 & 188 & +28 \\
\hline 4 & 312 & 85.0 & -73 & 2,420 & 2,160 & -10 \\
\hline 5 & 28.7 & 7.9 & -72 & 541 & 548 & +1 \\
\hline 6 & 18.3 & 8.2 & -45 & 352 & 368 & +4 \\
\hline \multicolumn{7}{|l|}{$\begin{array}{l}\text { Chief-cell } \\
\text { hyperplasia }\end{array}$} \\
\hline 1 & 33.6 & 8.3 & -75 & 628 & 774 & +23 \\
\hline 2 & 14.2 & 6.6 & -54 & 129 & 147 & +14 \\
\hline \multicolumn{7}{|l|}{ Carcinoma } \\
\hline 1 & 84.0 & 33.4 & -60 & 65.0 & 51.8 & -20 \\
\hline
\end{tabular}

Values shown in table represent means of three determinations. * cpm per milligram tissue protein insoluble in $10 \%$ TCA.

f Calcium is measured in millimoles/liter. 


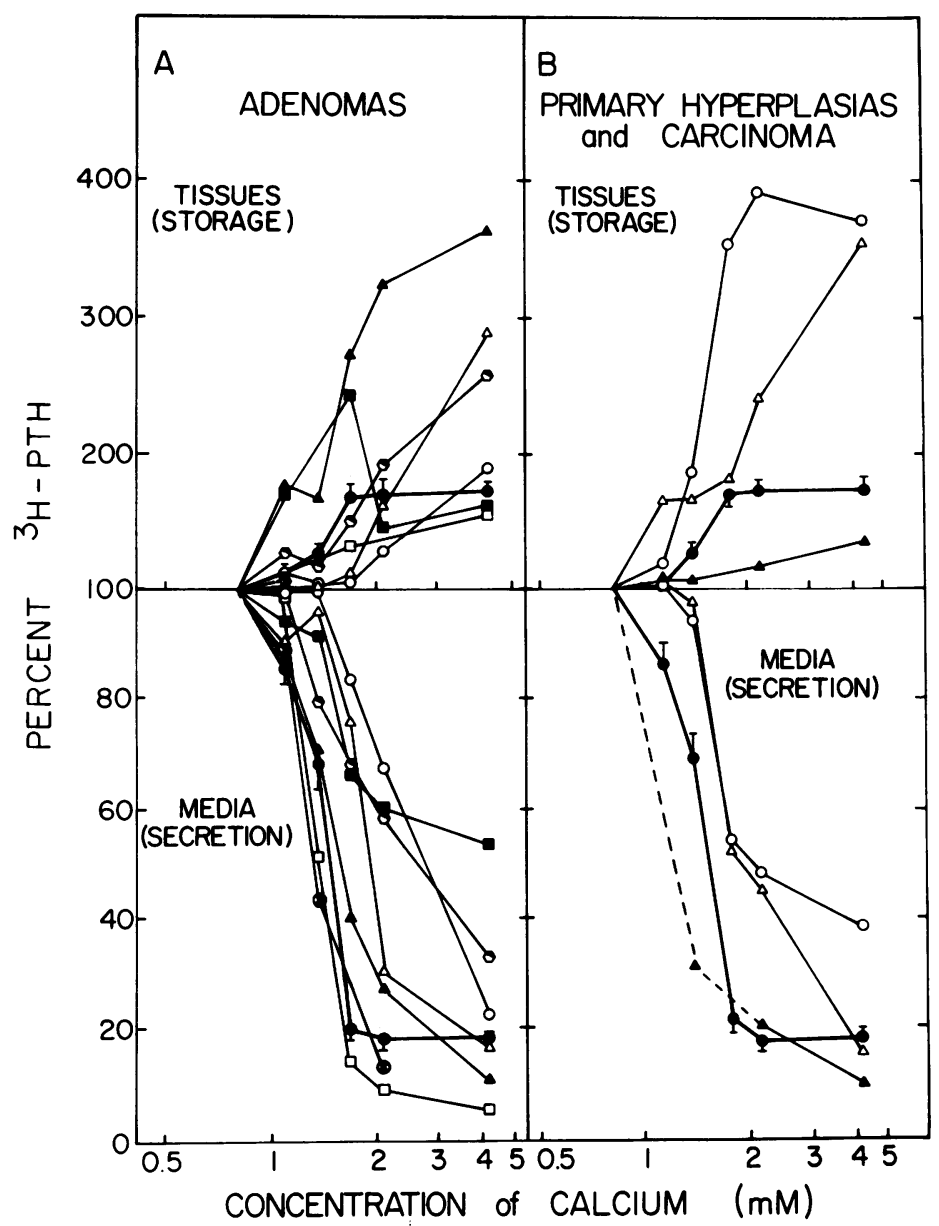

FIGURE 8 Effects of extracellular calcium concentrations on the release of PTH into media (lower panel) and on the content of PTH in tissues (upper panel) during incubation of parathyroid tissues for $4 \mathrm{~h}$ with $\left[{ }^{3} \mathrm{H}\right]$ leucine. Amounts of ${ }^{3} \mathrm{H}-\mathrm{PTH}$ were determined by polyacrylamide gel electrophoresis for each point. Results are expressed as percent of the value for maximum release of hormone at $0.5 \mathrm{mM}$ of calcium. (A) Parathyroid adenomas (human): $\square$, no. $1 ; \square$, no. $2 ; \Delta$, no. $3 ; \Delta$, no. $4 ; 0$, no. 5 ;, , no. 6 . Normal parathyroid glands for comparison: $\bullet$, bovine; $\otimes$, human. (B) Chief-cell hyperplasia (human): $O$, no. 1 , and $\Delta$, no. 2. Carcinoma of the parathyroid gland, $\Delta$.

of EDTA and calcium infusion on the concentrations of PTH in peripheral blood of patients with primary hyperparathyroidism (15). The studies in vitro, however, add to the studies done in vivo by providing a more direct assessment of parathyroid secretory response than is possible by the studies in vivo in which interpretations of measurements of changes in hormone concentrations in peripheral blood must take into account rates of metabolic clearance of hormone secretion. Birnbaumer et al. (17) have also found that hormone secretion from fragments of abnormal parathyroid glands responds to calcium when studied in vitro. In addition, Brown et al. (18) have reported in preliminary form the observations that adenomatous and hyperplastic tissues alike studied in suspension cul- tures in vitro retain their secretory responsiveness to changes in calcium concentrations.

If neoplastic parathyroid tissues retain their responsiveness to changes in extracellular levels of calcium, then the defect in secretory control that exists in these tissues must be other than that of simple autonomous secretion. At least two theories, both consistent with the observations made in the present studies, explain the defective process in which inappropriately high rates of PTH secretion may occur despite sustained hypercalcemia. First, the greatly increased mass of parathyroid tissue characteristic of neoplasia and hyperplasia may lead to an exaggeration of a normally small fractional component of secretion that remains insensitive to suppression by calcium. This nonsup- 


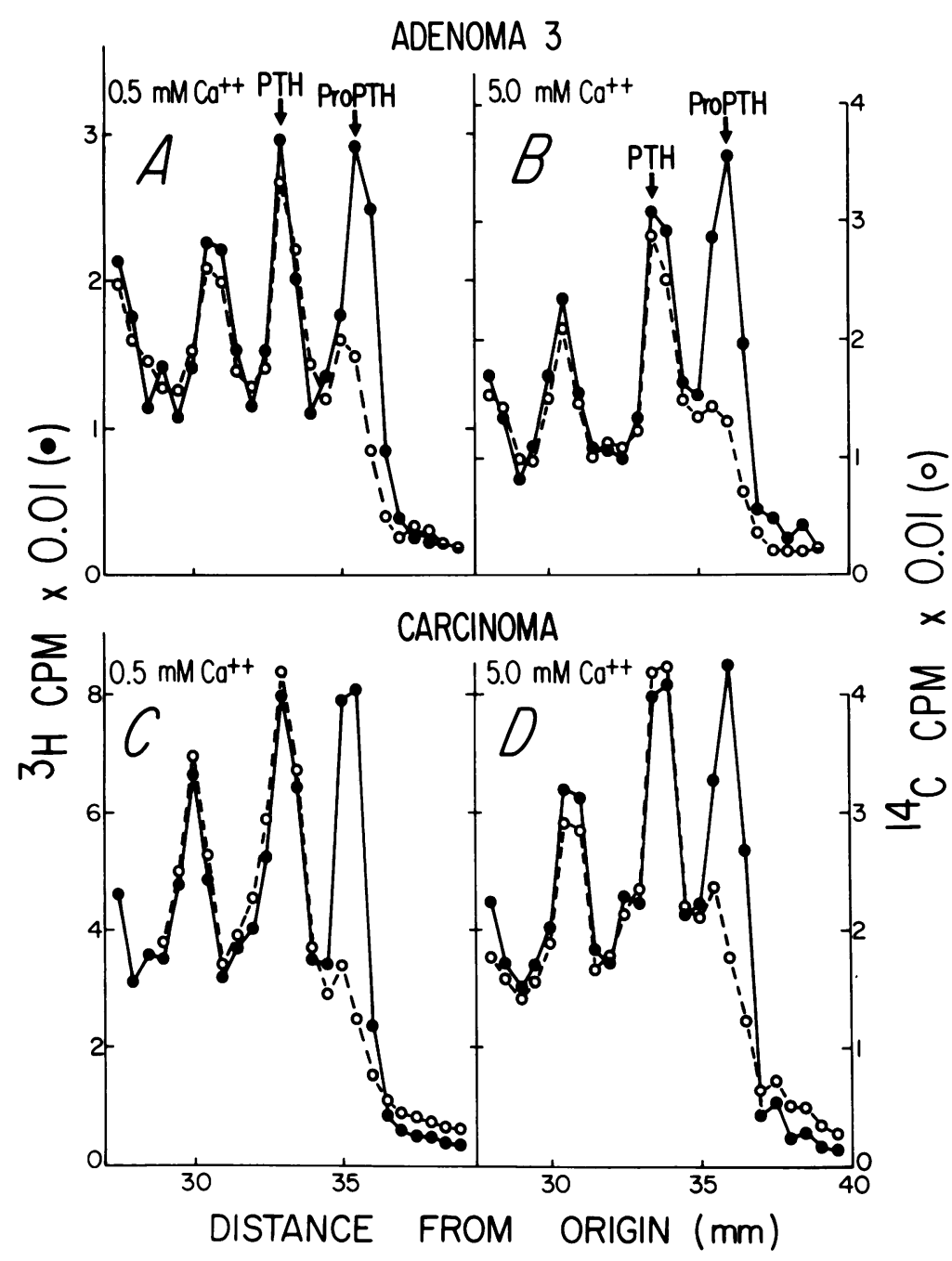

FIGURE 9 Electrophoretic patterns showing amounts of radiolabeled PTH and ProPTH synthesized during a 4-h incubation with $\left[{ }^{14} \mathrm{C}\right]$ leucine $(O)$ followed by a 30 -min pulse incubation with $\left[{ }^{3} \mathrm{H}\right]$ leucine of (A) Parathyroid adenoma no. 3 and (B) parathyroid carcinoma labeled with $\left[{ }^{3} \mathrm{H}\right]$ leucine. Electrophoresis was on $10 \%$ polyacrylamide gels containing $8 \mathrm{M}$ urea and $0.15 \mathrm{~N}$ potassium acetate. Only the region of the gels containing PTH and ProPTH are shown. ProPTH labeled with $\left[{ }^{14} \mathrm{C}\right]$ leucine was electrophoresed with the extracts of tissues as a marker.

pressible component of secretion was demonstrated previously in normal bovine parathyroid glands both in vivo $(5)$ and in vitro $(3,4)$. Second, the response to calcium of individual neoplastic and hyperplastic cells may be defective, i.e., although the cells respond to calcium it takes concentrations greater than normal to elicit a given response. This type of "set-point" error in PTH secretion was demonstrated recently in newborn calves. ${ }^{3}$

The present studies of the patterns of secretion of the neoplastic and hyperplastic parathyroid tissue suggest that both mechanisms may be responsible individ-

\footnotetext{
${ }^{3}$ Mayer, G. P. Unpublished observations.
}

ually or in combination to account for the defect in regulation of PTH secretion. The release of hormone was not completely suppressed even at concentrations of $5 \mathrm{mM}$ of calcium, concentrations that correspond to blood levels of $40 \mathrm{mg} / \mathrm{dl}$ when corrected for the fraction of calcium bound to serum proteins in whole blood. In addition, some of the tissues, compared with normal bovine and human parathyroids, required higher than normal concentrations of calcium to produce a given incremental change in these same parameters of cellular function. A "set-point" error thus appears to exist in these tissues. It is not clear why some of the adenomatous and hyperplastic tissues responded to calcium in a manner that was indistinguishable from 
TABLE III

Immunoreactive PTH Released from and Stored in Parathyroid Tissues In Vitro in Response to Varying Concentrations of Calcium

\begin{tabular}{|c|c|c|c|c|c|c|c|c|c|c|c|c|}
\hline \multirow{2}{*}{$\begin{array}{l}\text { Tissue prep- } \\
\text { aration }\end{array}$} & \multicolumn{6}{|c|}{ Media* } & \multicolumn{6}{|c|}{ Tissues* } \\
\hline & 0.5 & 1.0 & 1.5 & 2.0 & 2.5 & 5.0 & 0.5 & 1.0 & 1.5 & 2.0 & 2.5 & 5.0 \\
\hline & \multicolumn{12}{|c|}{ ng/mg tissue protein } \\
\hline $\begin{array}{l}\text { Normal } \\
\text { glands } \\
\text { (bovine) }\end{array}$ & $1,200 \pm 100 t$ & $870 \pm 53$ & $360 \pm 21$ & $250 \pm 22$ & $180 \pm 7$ & $220 \pm 27$ & $2,470 \pm 190$ & $2,570 \pm 240$ & $2,590 \pm 40$ & $2,860 \pm 30$ & $2,940 \pm 120$ & $3,430 \pm 240$ \\
\hline \multicolumn{13}{|l|}{ Adenomas } \\
\hline 1 & $1,370 \pm 230$ & $720 \pm 100$ & $352 \pm 56$ & $164 \pm 29$ & $162 \pm 17$ & $241 \pm 35$ & $924 \pm 85$ & $764 \pm 99$ & $648 \pm 88$ & $464 \pm 50$ & $798 \pm 76$ & $748 \pm 89$ \\
\hline 2 & - & $158 \pm 51$ & - & - & $98 \pm 6$ & - & - & $528 \pm 100$ & - & - & $215 \pm 38$ & - \\
\hline 3 & $985 \pm 30$ & $1,000 \pm 91$ & $544 \pm 19$ & $471 \pm 82$ & $496 \pm 58$ & $488 \pm 37$ & $1,790 \pm 206$ & $2,120 \pm 326$ & $4,530 \pm 212$ & $4,570 \pm 862$ & $5,230 \pm 878$ & $8,140 \pm 142$ \\
\hline 4 & $2,170 \pm 380$ & $1,770 \pm 380$ & $1,550 \pm 429$ & $782 \pm 160$ & $659 \pm 73$ & $176 \pm 28$ & $188 \pm 9$ & $114 \pm 28$ & $168 \pm 50$ & $110 \pm 17$ & $254 \pm 58$ & $331 \pm 27$ \\
\hline 5 & $1,340 \pm 259$ & $1,220 \pm 275$ & $865 \pm 130$ & $346 \pm 25$ & $524 \pm 69$ & $603 \pm 93$ & $794 \pm 159$ & $795 \pm 144$ & $732 \pm 58$ & $515 \pm 65$ & $1,998 \pm 411$ & $2,171 \pm 380$ \\
\hline 6 & $181 \pm 38$ & $170 \pm 32$ & $132 \pm 43$ & $129 \pm 36$ & $104 \pm 51$ & $78 \pm 21$ & $509 \pm 50$ & $429 \pm 89$ & $561 \pm 65$ & $630 \pm 64$ & $598 \pm 59$ & $549 \pm 58$ \\
\hline \multicolumn{13}{|l|}{$\begin{array}{l}\text { Chief-cell } \\
\text { hyperplasia }\end{array}$} \\
\hline 1 & $795 \pm 170$ & $815 \pm 178$ & $632 \pm 60$ & $309 \pm 27$ & $220 \pm 36$ & $357 \pm 39$ & $1,400 \pm 212$ & $1,020 \pm 269$ & $1,550 \pm 199$ & $1,650 \pm 227$ & $2,380 \pm 227$ & $2,470 \pm 303$ \\
\hline 2 & $47 \pm 3$ & $33 \pm 3$ & $45 \pm 4$ & $30 \pm 1$ & $23 \pm 2$ & $28 \pm 3$ & $68 \pm 4$ & $70 \pm 5$ & $76 \pm 7$ & $78 \pm 10$ & $83 \pm 3$ & $132 \pm 15$ \\
\hline \multicolumn{13}{|l|}{ Carcinoma } \\
\hline 1 & $14.1 \pm 4.0$ & - & $5.0 \pm 1.2$ & - & $5.3 \pm 1.1$ & $2.4 \pm 0.8$ & $24 \pm 2$ & - & $33 \pm 5$ & - & $26 \pm 4$ & $28 \pm 6$ \\
\hline
\end{tabular}

* Concentrations of calcium are measured in millimoles/liter.

f Mean \pm SEM for 5-12 determinations carried out in multiple dilutions.

normal tissues, whereas other adenomatous and hyperplastic tissues appeared to require abnormally high concentrations of calcium to suppress hormone release. Although great variability was found among the tissues in the amounts of hormone synthesis relative to total protein synthesis $(0.8$ to $14 \%$, Fig. 7$)$, no correlation of overall biosynthetic activity with responses to calcium was evident.

In contrast to these results are the observations of
Brown et al. (18) who found that, when studied in suspension cultures, cells from primary hyperplastic glands gave secretory responses that were close to those of normal bovine cells one-half maximum suppression at 0.9-1.1 mM calcium), whereas cells from adenomatous glands required 1.2-1.4 mM calcium to attain one-half maximum suppression. In view of the report by Fialkow et al. (34), who found that parathyroid adenomas are multicellular in origin and, hence, histologically

TABLE IV

Immunoreactive Proparathyroid Hormone in Tissues in Response to Varying Concentrations of Calcium In Vitro

\begin{tabular}{ccccccc}
\hline & \multicolumn{5}{c}{ Concentrations of calcium* } \\
\cline { 2 - 7 } Tissue preparation & 0.5 & 1.0 & 1.5 & 2.0 & 2.5 & 5.0 \\
\hline $\begin{array}{c}\text { Normal glands } \\
\text { (bovine) }\end{array}$ & $173 \pm 10 \ddagger$ & $161 \pm 11$ & $153 \pm 12$ & $151 \pm 10$ & $148 \pm 7$ & $139 \pm 11$ \\
Adenomas & & & & & & \\
1 & $128 \pm 9$ & $126 \pm 7$ & $119 \pm 8$ & $94 \pm 2$ & $62 \pm 6$ & $85 \pm 12$ \\
3 & $53 \pm 6$ & $53 \pm 8$ & $54 \pm 10$ & $50 \pm 4$ & $68 \pm 6$ & $57 \pm 5$ \\
5 & $21 \pm 2$ & $28 \pm 4$ & $24 \pm 4$ & $24 \pm 5$ & $29 \pm 4$ & $32 \pm 5$ \\
6 & $35 \pm 4$ & $30 \pm 3$ & $18 \pm 4$ & $24 \pm 2$ & $14 \pm 4$ & $14 \pm 1$ \\
Hyperplasia & & & & & & \\
1 & $20 \pm 2$ & - & $28 \pm 4$ & $31 \pm 6$ & $25 \pm 4$ & $24 \pm 3$ \\
Carcinoma & & & & & & \\
1 & $15 \pm 3$ & - & $17 \pm 1$ & - & $22 \pm 2$ & - \\
\hline
\end{tabular}

* Concentrations of calcium are measured in millimoles/liter.

\$ Mean \pm SEM determined by radioimmunoassay in 4-8 dilutions. 
TABLE V

Precipitation of Parathyroid Hormonal Peptides by TCA

\begin{tabular}{llr}
\hline & \multicolumn{2}{c}{$\begin{array}{c}\text { Radioactive protein insoluble } \\
\text { in TCA }\end{array}$} \\
\cline { 2 - 3 } \multicolumn{1}{c}{ Peptide* $^{*}$} & \multicolumn{2}{c}{$\%$} \\
& \multicolumn{3}{c}{$\%$ acid } & $12.5 \%$ acid \\
\hline bPTH(1-84) & $94.0 \pm 1.5 \$$ & $92.2 \pm 3.1$ \\
hPTH $(1-34)^{\prime \prime}$ & $96.6 \pm 2.0$ & $91.0 \pm 2.4$ \\
[Tyr-34]bPTH(1-34)" & $95.2 \pm 2.1$ & $91.2 \pm 0.8$ \\
bPTH(34-84)" & $78.3 \pm 1.3$ & $75.5 \pm 1.9$ \\
bPTH(1-13)" & $51.2 \pm 0.6$ & $42.2 \pm 0.6$ \\
[Tyr-13]bPTH(1-13)" & $67.4 \pm 0.9$ & $58.9 \pm 2.2$ \\
bPTH(53-84) & $81.1 \pm 1.2$ & $74.1 \pm 1.1$ \\
hPTH(53-84)" & $86.2 \pm 2.0$ & $81.6 \pm 3.2$ \\
bPTH $(25-48)^{\prime \prime}$ & $74.5 \pm 1.1$ & $65.0 \pm 1.9$ \\
bPTH $(44-68)^{\prime \prime}$ & $32.6 \pm 1.9$ & $27.1 \pm 2.0$ \\
\end{tabular}

* 50-120 pg of radioiodinated ${ }^{125}$ I-peptides $(10,000-130,000$ cpm) were added to $0.3 \mathrm{ml}$ of Eagle's Minimum Essential Medium containing $5 \%$ fetal calf serum and were twice precipitated in cold TCA (the initial acid-insoluble precipitate was dissolved in $0.2 \mathrm{ml}$ of $0.5 \mathrm{~N}$ sodium hydroxide). Precipitates were collected by centrifugation, and radioactivity in precipitates and supernates was measured in a gamma spectrometer.

I Native bovine PTH.

\$ Prepared by gel filtration (Bio-Gel P-100) of dog plasma obtained 30 min after injection of radioiodinated bPTH.

"Prepared by solid-phase synthesis.

ף Prepared by tryptic cleavage of maleoylated PTH.

can be considered as "localized" hyperplasia, there is no obvious reason why primary hyperplasia and adenomas should give differing responses to calcium.

Fragments of PTH were produced and secreted by parathyroid glandular tissues. But in these as well as in our previous studies of hormone secretion in vitro $(4,19,29)$ and in vivo $(10)$, the predominant form of the hormone identified was indistinguishable from intact hormone. Immunoreactive hormone of molecular weight smaller than intact PTH has been in the minority. Birnbaumer et al. (17) have made similar observations in their studies of hormone secretion in vitro. For example, in the studies described in this report, only a small amount of the total immunoreactive material in the extracts migrated electrophoretically faster than PTH (Figs. 2 and 4), and, in some of the extracts, the only immunoreactivity observed corresponded to intact PTH (Fig. 1). Other workers, however, reported finding large quantities of fragments not only in extracts of parathyroid adenomas $(8,32)$ and in parathyroid effluent blood (33) but also released by parathyroid glands incubated in vitro for longer than $6 \mathrm{~h}$ (3537). The reasons for these different observations are not apparent. In view of a recent report that $\mathrm{COOH}$ - terminal fragments in extracts of parathyroid adenomas remain soluble after treatment with TCA (32), the possibility is raised that the lack of detection of substantial amounts of PTH fragments in the present studies could be the result of a failure to recover them in the acidinsoluble precipitates prepared from the extracts of tissues and media. Treatments, however, of several different radioiodinated fragments of PTH with TCA under conditions that were identical to those used to prepare extracts of parathyroid tissues and media showed that all but the smallest fragment, bPTH(113), were recovered in substantial yields. It is possible, however, as suggested by Silverman and Yalow (8), that hormonal fragments in parathyroid tissues arise by degradative processes after collection and during storage of the parathyroid tissues. In this regard, Keutmann et al. (38) observed substantial quantities of acidsoluble hormonal fragments in extracts prepared from pooled human parathyroid tissues that had been frozen and stored for several months before extraction, whereas extracts prepared immediately (within 1-2 h) after the tissues were obtained from the operating room did not contain detectable amounts of either acid-soluble or -insoluble fragments. ${ }^{4}$ Additional stdies will be required to resolve the issues concerning the amounts and physiological significance of PTH fragments contained within parathyroid glands, as well as the circumstances under which they are released from the glands.

\section{ACKNOWLEDGMENTS}

I thank B. Kemper, H. O. Gircys, and P. C. Dee for their help with the experiments, C. A. Wang and S. I. Roth for providing the parathyroid tissues, and L. B. Fred for editorial assistance.

\section{REFERENCES}

1. Albright, F., and E. C. Reifenstein, Jr. 1948. The Parathyroid Glands and Metabolic Bone Disease: Selected Studies. The Williams \& Wilkins Co., Baltimore, Md.

2. Cope, O., B. A. Barnes, B. Castleman, G. C. E. Mueller, and S. I. Roth. 1961. Vicissitudes of parathyroid surgery: trials of diagnosis and management of 51 patients with a variety of disorders. Ann. Surg. 154: 491-508.

3. Targovnik, J. H., J. S. Rodman, and L. M. Sherwood. 1971. Regulation of parathyroid hormone secretion in vitro: quantitative aspects of calcium and magnesium ion control. Endocrinology. 88: 1477-1482.

4. Habener, J. F, and J. T. Potts, Jr. 1976. Relative effectiveness of magnesium and calcium on the secretion and biosynthesis of parathyroid hormone in vitro. Endocrinology. 98: 197-202.

5. Mayer, G. P., J. F. Habener, and J. T. Potts, Jr. 1976. Parathyroid hormone secretion in vivo. Demonstration of a calcium-independent, nonsuppressible component of secretion. J. Clin. Invest. 57: 678-683.

6. Gittes, R. F., and I. C. Radde. 1966. Experimental hyper-

\footnotetext{
${ }^{4}$ Keutmann, H. T. Personal communication.
} 
parathyroidism from multiple isologous parathyroid transplants: homeostatic effect of simultaneous thyroid transplants. Endocrinology. 78: 1015-1022.

7. Canterbury, J. M., and E. Reiss. 1972. Multiple immunoreactive molecular forms of parathyroid hormone in human serum. Proc. Soc. Exp. Biol. Med. 140: 1393-1398.

8. Silverman, R., and R. S. Yalow. 1973. Heterogeneity of parathyroid hormone. Clinical and physiologic implications. J. Clin. Invest. 52: 1958-1971.

9. Goldsmith, R. S., J. Furszyfer, W. J. Johnson, A. E. Fournier, G. W. Sizemore, and C. D. Arnaud. 1973. Etiology of hyperparathyroidism and bone disease during chronic hemodialysis. III. Evaluation of parathyroid suppressibility. J. Clin. Invest. 52: 173-180.

10. Habener, J. F., D. Powell, T. M. Murray, G. P. Mayer, and J. T. Potts, Jr. 1971. Parathyroid hormone: secretion and metabolism in vivo. Proc. Natl. Acad. Sci. U. S. A. 68: 2986-2991.

11. Segre, G. V., J. F. Habener, D. Powell, G. W. Tregear, and J. T. Potts, Jr. 1972. Parathyroid hormone in human plasma. Immunochemical characterization and biological implications. J. Clin. Invest. 51: 3163-3172.

12. Hruska, K. A., R. Kopelman, W. E. Rutherford, S. Klahr, E. Slatopolsky, A. Greenwalt, T. Bascom, and J. Markham. 1975. Metabolism of immunoreactive parathyroid hormone in the dog. J. Clin. Invest. 56: 39-48.

13. Canterbury, J. M., L. A. Bricker, G. S. Levey, P. L. Kozlovskis, E. Ruiz, J. E. Zull, and E. Reiss. 1975. Metabolism of bovine parathyroid hormone. Immunological and biological characteristics of fragments generated by liver perfusion. J. Clin. Invest. 55: 1245-1253.

14. Reiss, E., and J. M. Canterbury. 1969. Primary hyperparathyroidism: application of radioimmunoassay to differentiation of adenoma and hyperplasia and to preoperative localization of hyperfunctioning parathyroid glands. N. Engl. J. Med. 280: 1381-1385.

15. Murray, T. M., M. Peacock, D. Powell, J. M. Monchik, and J. T. Potts, Jr. 1972. Non-autonomy of hormone secretion in primary hyperparathyroidism. Clin. Endocrinol. 1: 235-246.

16. Reiss, E., and J. M. Canterbury. 1974. Spectrum of hyperparathyroidism. Am. J. Med. 56: 794-799.

17. Birnbaumer, M. E., A. B. Schneider, D. Palmer, D. A. Hanley, and L. M. Sherwood. 1977. Secretion of parathyroid hormone by abnormal parathyroid glands in vitro. J. Clin. Endocrinol. Metab. 45: 105-113.

18. Brown, E., S. Hurwitz, M. Brennan, S. Marx, A. Spiegel, J. Koehler, and G. Aurbach. 1977. Distinct calcium sensitivity in cells prepared from adenomatous vs. hyperplastic glands in primary hyperparathyroidism. Clin. Res. 25: 387A. (Abstr.)

19. Habener, J. F., B. Kemper, and J. T. Potts, Jr. 1975. Calcium-dependent intracellular degradation of parathyroid hormone: a possible mechanism for the regulation of hormone stores. Endocrinology. 97: 431-441.

20. Keutmann, H. T., P. M. Barling, G. N. Hendy, G. V. Segre, H. D. Niall, G. D. Aurbach, J. T. Potts, Jr., and J. L. H. O'Riordan. 1974. Isolation of human parathyroid hormone. Biochemistry. 13: 1646-1652.

21. Tregear, G. W., J. van Rietschoten, E. Greene, H. D. Niall, H. T. Keutmann, J. A. Parsons, J. L. H. O’Riordan, and J. T. Potts, Jr. 1974. Solid-phase synthesis of the biologically active N-terminal 1-34 peptide of human parathyroid hormone. Hoppe-Seyler's Z. Physiol. Chem. 355: 415-421.

22. Keutmann, H. T., H. D. Niall, J. L. H. O'Riordan, and J. T. Potts, Jr. 1975. A re-investigation of the amino-ter- minal sequence of human parathyroid hormone. Biochemistry. 14: 1842-1847.

23. Segre, G. V., H. D. Niall, R. T. Sauer, and J. T. Potts, Jr. 1977. Edman degradation of radioiodinated parathyroid hormone: application to sequence analysis and hormone metabolism in vivo. Biochemistry. 16: 2417-2427.

24. Habener, J. F., and J. T. Potts, Jr. 1976. Radioimmunoassay of parathyroid hormone. In Hormones in Human Blood: Detection and assay. H. N. Antoniades, editor. Harvard University Press, Cambridge, Mass. 551-588.

25. Trudeau, D. L., and E. F. Freier. 1967. Determination of calcium in urine and serum by atomic absorption spectrophotometry. Clin. Chem. 13: 101-114.

26. Habener, J. F., and J. T. Potts, Jr. 1975. Technique for the identification of a biosynthetic precursor of parathyroid hormone. Methods Enzymol. 37: 345-360.

27. Laemmli, U. K. 1970. Cleavage of structural proteins during the assembly of the head of bacteriophage T4. Nature (Lond.). 227: 680-685.

28. Habener, J. F., T. D. Stevens, G. W. Tregear, and J. T. Potts, Jr. 1976. Radioimmunoassay of human proparathyroid hormone: analysis of hormone content in tissue extracts and in plasma. J. Clin. Endocrinol. Metab. 42: 520530.

29. Kemper, B. [W.], J. F. Habener, A. Rich, and J. T. Potts, Jr. 1974. Parathyroid secretion: discovery of a major calcium-dependent protein. Science(Wash.D.C.). 184: 167169.

30. Kemper, B., J. F. Habener, J. T. Potts, Jr., and A. Rich. 1972. Proparathyroid hormone: identification of a biosynthetic precursor to parathyroid hormone. Proc. Natl. Acad. Sci. U.S. A. 69: 643-647.

31. Cohn, D. V., R. R. MacGregor, L. L. H. Chu, J. R. Kimmel, and J. W. Hamilton. 1972. Calcemic fraction-A: biosynthetic peptide precursor of parathyroid hormone. Proc. Natl. Acad. Sci. U. S. A. 69: 1521-1525.

32. Di Bella, F. P., J. Gilkinson, K. Zawistowski, and C. D. Arnaud. 1976. COOH-terminal fragments of human parathyroid hormone (hPTH): extraction from parathyroid tumors, characterization, and utility for the production of clinically-useful antisera for measurement of hPTH. Program, Abstracts, 58th Annual Meeting, Endocrine Society. Abstr. No. 100. 106.

33. Flueck, J., F. P. Di Bella, A. J. Edis, J. M. Kehrwald, and C. D. Arnaud. 1977. Immunoheterogeneity of parathyroid hormone in venous effluent serum from hyperfunctioning parathyroid glands. J. Clin. Invest. 60: 1367-1375.

34. Fialkow, P. J., C. E. Jackson, M. A. Block, and K. A. Greenawald 1977. Multicellular origin of parathyroid "adenomas." N. Engl. J. Med. 297: 696-698.

35. Sherwood, L. M., J. S. Rodman, and W. B. Lundberg. 1970. Evidence for a precursor to circulating parathyroid hormone. Proc. Natl. Acad. Sci. U. S. A. 67: 1631-1638.

36. Fischer, J. A., S. B. Oldham, G. W. Sizemore, and C. D. Arnaud. 1972. Calcium-regulated parathyroid hormone peptidase. Proc. Natl. Acad. Sci. U. S. A. 69: 2341-2345.

37. Potts, J. T., Jr., H. T. Keutmann, H. D. Niall, J. F. Habener, G. W. Tregear, L. J. Deftos, J. L. H. O'Riordan, and G. D. Aurbach. 1972. Chemistry of the parathyroid hormones: clinical and physiological implications. In Calcium, Parathyroid Hormone and the Calcitonins. R. V. Talmage and P. L. Munson, editors. Excerpta Medica Foundation, Amsterdam. 159-172.

38. Keutmann, H. T., G. N. Hendy, M. Boehnert, J. L. H. O'Riordan, and J. T. Potts, Jr. 1978. Purification of human parathyroid hormone: recent studies and further observations. J. Endocrinol. 78: 222. 